\title{
TIESAS JURISDIKCIJA SASKAN̦Ā AR KONVENCIJU PAR KRAVU STARPTAUTISKO AUTOPĀRVADĀJUMU LĪGUMU (CMR)
}

\section{COURT JURISDICTION PURSUANT TO THE CONVENTION ON THE CONTRACT FOR THE INTERNATIONAL CARRIAGE OF GOODS BY ROAD (CMR)}

\author{
Aleksandrs Fillers, Dr. iur., LL.M. \\ Rīgas Juridiskās Augstskolas docents, \\ Latvijas Universitātes pasniedzējs
}

\begin{abstract}
Summary
Convention on the Contract for the International Carriage of Goods by Road (CMR) is one of the leading conventions containing uniform private law rules. Most of its rules are substantive and regulate different aspects of the international contract of carriage. However, the CMR also contains jurisdictional rules. The article is intended as a short commentary on Article 31(1) CMR that establishes a rather specific jurisdictional regime for disputes arising from international contracts of carriage. Every time when a court faces a dispute related to a contract of carriage covered by the CMR, it must establish its jurisdiction. Thus, it is particularly important to clarify the most important issues concerning the application of Article 31(1) CMR.
\end{abstract}

Atslēgvārdi: CMR, starptautiskā jurisdikcija, teritoriālā piekritība, vienošanās par jurisdikciju.

Keywords: CMR, international jurisdiction, domestic jurisdiction, jurisdictional agreements.

\section{Ievads}

Konvencija par kravu starptautisko autopārvadājumu līgumu ${ }^{1}$ (turpmāk CMR) ir viena no svarīgākajām starptautiskajām konvencijām privāttiesību jomā, kuras mērḳis ir standartizēt atsevišķus starptautiskā autopārvadājuma līguma noteikumus. ${ }^{2}$ Šajā konvencijā ir ietverta virkne materiāltiesisko normu,

${ }^{1}$ Konvencija par kravu starptautisko autopārvadājumu līgumu. Parakstīta Ženēvā 19.05.1956. CMR tulkojums latviešu valodā ir pieejams: https:/likumi.lv/ta/lv/starptautiskie-ligumi/id/673-konvencija-par-kravu-starptautisko-autoparvadajumu-ligumu-cmr-un-parakstisanas-protokols [aplūkots 20.04.2021.].

2 Messent A., Glass D. A. Hill \& Messent CMR: Contracts for the International Carriage of Goods by Road, $3^{\text {rd }}$ ed. London: LLP, 2000, p. 2. 
kas regulē starptautisko autopārvadājumu līgumus. Tomēr, lai arī vairākums CMR normu ir materiāltiesiskas, dažas konvencijas normas attiecas uz civilprocesu, regulējot tiesu jurisdikciju un ārvalstu spriedumu izpildi. ${ }^{3}$ Proti, CMR 31. panta pirmajā daḷā (turpmāk - 31(1). pants) ir noteikts: "Par strīdīgiem jautājumiem, kas rodas, veicot pārvadājumus pēc šīs konvencijas, prasītājs var ierosināt prāvu jebkurā Līgumslēdzēju Valstu norādītajā tiesā, kā arī tās valsts tiesā, kur atrodas: a) atbildētāja dzīvesvieta, viṇa galvenais uzṇēmums, iestāde vai birojs, ar kuru ir noslēgts līgums par pārvadājumu; b) kravas nosūtīšanas vai kravas piegādāšanas vieta, un nevienā citā tiesā." No minētās normas teksta izriet, ka CMR paredz vairākus alternatīvus jurisdikcijas pamatus, kā arī papildus l̦auj pašām līguma pusēm vienoties par jurisdikciju. Arī Latvijas praksē tiesām ir bijusi nepieciešamība saskarties ar šo normu piemērošanu. ${ }^{4}$ Tādēḷ jo ippaši svarīgi ir ieskicēt šīs normas darbības principus. Tas arī ir šī raksta mērḳis: sniegt īsu pārskatu par CMR 31(1). panta tvērumu un tajā ietverto jurisdikcijas pamatu piemērošanu.

\section{CMR 31(1). panta vispārīgs raksturojums}

CMR 31(1). pants nosaka tiesu starptautisko jurisdikciju ${ }^{5}$ un šo jautājumu regulē izsmel̦oši. ${ }^{6}$ Tas nozīmē, ka CMR jurisdikcijas pamatiem ir prioritāte pār Briseles Ibis regulā $\overline{ }^{7}$ noteiktajiem jurisdikcijas pamatiem, kad jautājums par jurisdikciju ir jāizlemj Eiropas Savienības dalībvalsts tiesai. ${ }^{8}$ Izṇēmums būs tad, ja attiecīgo jautājumu CMR 31(1). pants neregulē. ${ }^{9}$ Šāds secinājums izriet no Briseles Ibis regulas 71. panta otrās daļas a) punkta.

Vienlaikus ir jānorāda, ka CMR 31(1). panta piemērošana izslēdz iespēju noteikt starptautisko jurisdikciju, izmantojot nacionālās tiesību normas. ${ }^{10}$ Nacionālo tiesību piemērošana, ja tā novestu pie rezultāta, kas ir pretrunā ar CMR 31(1). pantu, būtu uzskatāma par valstij saistoša līguma pārkāpumu. Te ir svarīgi atzīmēt, ka CMR jurisdikcijas normām ir imperatīvs raksturs un lìguma puses tās nevar grozīt. ${ }^{11}$ Tomēr pastāv divi izṇēmumi. Pirmkārt, pašā CMR 31(1). pantā ir paredzēta iespēja pusēm vienoties, ka vēl kādai CMR līgumslēdzēja valstij būs jurisdikcija. Otrkārt, ir izteikts viedoklis, ka vienošanās par tiesas jurisdikciju, ja tā ir noslēgta jau pēc strīda rašanās, vairs nav pakḷauta

\footnotetext{
3 Šajā rakstā tiks apskatīti tikai jurisdikcijas jautājumi, bet problēmjautājumi, izpildot ārvalstu spriedumus, pamatojoties uz CMR normām, netiks skarti.

${ }^{4}$ Sk., piem., Rēzeknes tiesas 05.03.2020. spriedumu lietā Nr. C-0470-20. Pieejams: https://manas.tiesas.lv/ eTiesasMvc/nolemumi/pdf/415659.pdf [aplūkots 20.04.2021.].

5 Canaris C.-W., Habersack M., Schäfer C. (Hrsg.). Staub. Handelsgesetzbuch: Großkommentar. Band 14. 5. Aufl. Berlin: De Gruyter, 2017, S. 633, 641.

${ }^{6}$ Ibid., S. 634, 641; Schmidt K., Herber R. (Hrsg.). Münchener Kommentar zum Handelsgesetzbuch. Band 7. 3. Aufl. München: C. H. Beck, 2014, S. 1816; Messent A. 2000, p. 242.

7 Eiropas Parlamenta un Padomes Regula Nr. 1215/2012 par jurisdikciju un spriedumu atzīšanu un izpildi civillietās un komerclietās. Pieṇemta 12.12.2012.

8 Canaris C.-W. 2017, S. 634; Schmidt K. 2014, S. 1816.

9 Ibid.

10 Messent A. 2000, p. 242; Loewe R. Commentary on the Convention of 19 May 1956 on the Contract for the International Carriage of Goods by Road (CMR), 1975, p. 63. Pieejams: http://folk.uio.no/erikro/ WWW/cog/commentaryCMR.pdf [aplūkots 12.03.2021.].

11 Putzeys J. Le contrat de transport routier de marchandises. Bruxelles: Bruylant, 1981, p. 372.
} 
CMR 31(1). panta prasībām. ${ }^{12}$ Tādā gadījumā, n,emot vērā, ka Briseles Ibis regula var tikt piemērota jautājumiem, kuri nav atrisināti CMR, šādas vienošanās forma un iespēja noteikt kādas tiesas ekskluzīvu jurisdikciju būtu nosakāmas saskaṇā ar šo regulu. Tomēr uzskats, ka šādas vienošanās nebūs pakḷautas CMR, nav viennozìmīgs un par to ir izteiktas arī šaubas. ${ }^{13}$

Padziḷinātai CMR 31(1). panta analīzei ir jāizškirir trīs šīs normas elementi: 1) tās tvērums; 2) objektīvās piesaistes un 3) subjektīvā piesaiste. Turpmākā šīs normas analīze sekos šai struktūrai.

\section{31(1). panta tvērums}

31(1). pants iesākas ar frāzi "Par strīdīgiem jautājumiem, kas rodas, veicot pārvadājumus pēc šìs Konvencijas [..]”. Šajā frāzē ir ietverts attiecīgās normas tvērums. Acīmredzami, ka visi prasījumi, kas ir pamatoti ar pārvadājuma līgumu, kā arī ārpuslīgumiski prasījumi, kas ir saistīti ar šāda līguma izpildi, ${ }^{14}$ ietilpst 31(1). panta tvērumā. ${ }^{15}$ Savukārt visi strīdi, kas nav cieši saistīti ar šādu lìgumu, pat ja tie rodas starp līguma pusēm, nebūs paḳ̣auti CMR 31(1). pantam. ${ }^{16}$ CMR 31(1). panta kontekstā nav nozìmes tam, vai prasību ceḷ pārvadātājs, nosūtītājs vai kravas saṇēmējs. ${ }^{17}$ Šeit ir īpaši jāuzsver, ka kravas saṇēmēja prasījums pret pārvadātāju ir ietverts CMR 13. panta pirmajā daḷā, bet CMR 13. panta otrajā daḷā ir ietverts pārvadātāja prasījums pret kravas saṇēmēju. Arī tad, ja prasība tiesā ir pamatota ar kādu no šiem prasījumiem, tā ietilps CMR 31(1). panta tvērumā.

Jānorāda, ka CMR būs piemērojama arī tiem prasījumiem, kas izriet no pārvadājuma līguma, bet kurus tieši neregulē konvencijas materiāltiesiskās normas. ${ }^{18}$ Tāpēc arī tad, ja pārvadātājs cel̦ prasību pret kravas nosūtītāju par samaksu, šāda prasība ietilps CMR 31(1). panta tvērumā, lai arī CMR tieši neregulē šādu prasījumu. ${ }^{19}$

Tomēr doktrīnā ir izteikts arī viedoklis, ka CMR 31(1). pants nav piemērojams, ja pārvadājums vispār nav ticis iesākts. ${ }^{20}$ Šo viedokli mēgina pamatot gan ar to,

12 Mankowski P. (ed.). Commercial Law: Article-by-Article Commentary. Baden-Baden: Beck, 2019, p. 969; Clarke M. A. International Carriage of Goods by Road: CMR, $6^{\text {th }}$ ed. New York: Informa Law, 2014, p. 161; Putzeys J. 1981, p. 376.

13 Clarke M. A. 2014, p. 161.

14 Tā kā saskaṇā ar CMR 28. panta otro daḷu arī ārpuslīgumiski prasījumi pret pārvadātāju ir pakḷauti CMR materiāltiesiskajam regulējumam, arī tiem ir piemērojams CMR 31. pants. Sk.: Canaris C.-W. 2017, S. 637. Ja ārpuslīgumisks prasījums saskaņā ar CMR 28. panta otro daḷu ir vērsts pret CMR 3. pantā minētu pārvadātāja palīgu, kurš pats nav bijis pārvadājuma līguma puse, tad tas ietilps CMR 31(1). panta tvērumā tikai tad, ja šāds palīgs zināja vai tam vajadzēja zināt, ka pārvadājuma līgumam būs piemērojams CMR. Tātad palīgam būtu jāzina ne tikai tas, ka viņš piedalās starptautiska pārvadājuma izpildē, bet arī tas, ka līgumā norādītās kravas nosūtī̌anas un saņemšanas vietas atrodas divās dažādās valstīs un vismaz viena no tām ir CMR līgumslēdzēja valsts. Ibid., S. 638.

15 Putzeys J. 1981, p. 373.

16 Ibid., p. 374.

17 Canaris C.-W. 2017, S. 636.

18 Loewe R. 1975, p. 63.

${ }^{19}$ CMR regulē pārvadātāja tiesības uz samaksu 13. panta kontekstā; taču neregulē vispārīgi pārvadātāja tiesības pieprasīt samaksu no nosūtītāja. Jānorāda gan, ka patiesībā atsevišķas CMR normas būs piemērojamas arī šādam prasījumam. Tā CMR 32. pantā paredzētais noilgums attieksies arī uz šādu prasījumu. Tādēl nebūtu pareizi apgalvot, ka CMR normām vispār nav nekādas ietekmes uz šādu prasījumu.

${ }^{20}$ Messent A. 2000, p. 243; Loewe R. 1975, p. 63. 
ka CMR 31(1). pantā ir runa "par strīdīgiem jautājumiem, kas rodas, veicot pārvadājumus [..]", gan ar to, ka CMR 31(1). panta b) punktā ir tieši minēta "kravas [faktiskā] nosūtǐšanas vieta”, kas var tikt noteikta tikai pēc tam, kad pārvadātājs ir saṇēmis kravu nosūtīšanai. ${ }^{21}$ Taču šāds viedoklis nav pamatots. Saskaṇā ar CMR 1. pantu konvencija ir piemērojama nevis pārvadājumam, bet pārvadājuma līgumam, turklāt CMR 4. pants faktiski regulē arī paša līguma noslēgšanas atsevišķus aspektus. Lìdz ar to nav nekāda pamata sašaurināt CMR 31(1). panta tvērumu, bet tas ir jāattiecina arī uz tādiem strīdiem, kas izriet no pārvadājuma līguma jau no brīža, kad šāds līgums ir noslēgts. ${ }^{22}$ Turklāt tiek arī norādīts, ka CMR 31(1). panta b) punkts satur tikai vienu no alternatīvām jurisdikcijas piesaistēm, kuras mērķis ir dot prasītājam plašāku tiesu izvēli, nevis noteikt CMR 31(1). panta tvērumu. ${ }^{23}$

\section{31(1). panta objektīvās piesaistes}

Ja prasība ietilps CMR 31(1). panta tvērumā, tad ir jānoskaidro, kurā tiesā prasītājs var vērsties saskaṇā ar šo normu. CMR 31. pants paredz šādas objektīvās piesaistes: 1) atbildētāja dzīvesvieta; 2) atbildētāja galvenais uzṇēmums; 3) vieta, kurā atrodas atbildētāja iestāde vai birojs, ar kuru ir noslēgts līgums par pārvadājumu; 4) kravas nosūtīšanas vieta un 5) kravas piegādāšanas vieta. Starp šìm piesaistēm nav nekādas hierarhijas ${ }^{24}$, un līgumslēdzēju valstīm ir pienākums nodrošināt, ka prasītājam ir iespēja celt prasību jebkurā no CMR 31(1). pantā minētajām tiesām. ${ }^{25}$

CMR objektīvās piesaistes nosaka tikai starptautisko jurisdikciju, bet katras valsts iekšèjās teritoriālās piekritības normas nosaka, kādā konkrētā tiesā varēs celt prasību. ${ }^{26}$ Tas nozīmē, ka arī tad, ja atbildētāja dzìvesvieta vai galvenais uzṇēmums ir Latvijā, no tā varēs secināt vien to, ka prasītājs varēs celt prasību Latvijas tiesās. Tomēr arī šeit ir svarīga nianse. Briseles Ibis regulas 7. pantā ir paredzēta ne tikai starptautiskā jurisdikcija, bet arī teritoriālā piekritība. ${ }^{27} \mathrm{Lìdz}$ ar to situācijā, kad prasība, saskaṇā ar CMR 31(1). panta objektīvu piesaisti, tiks celta tādā Eiropas Savienības dalībvalstī, kas ir arī lïguma izpildes vieta regulas $7(1)(\mathrm{b})$. panta izpratnē, ${ }^{28}$ prasītājam būs jācel̦ prasība tieši tajā tiesā, uz kuru norāda regulas norma. Šàdu risinājumu pamato tas apstāklis, ka, ja jau CMR neregulē teritoriālo piekritību, bet Briseles Ibis regulā šāds regulējums ir, tad regulai ir jāaizpilda CMR robs.

${ }^{21}$ Theunis J. (ed.). International Carriage of Goods by Road (CMR). London: LLP, 1987, p. 148.

22 Mankowski P. 2019, p. 969; Clarke M. A. 2014, p. 155; Schmidt K. 2014, S. 1813; Putzeys J. 1981, p. 373.

23 Clarke M. A. 2014, p. 155.

24 Putzeys J. 1981, p. 374.

25 Loewe R. 1975, p. 65.

${ }^{26}$ Putzeys J. 1981, pp. 376-377; Loewe R. 1975, p. 65.

${ }^{27}$ Sk.: Fillers A. Briseles Ibis regulas piemērošana Latvijas tiesās. Grām.: Starptautisko un Eiropas Savienības tiesību piemērošana nacionālajās tiesās. Latvijas Universitātes 78. starptautiskās zinātniskās konferences rakstu krājums. Rīga: LU Akadēmiskais apgāds, 2020, 68. lpp.

${ }^{28}$ Briseles Ibis regulas 7. panta kontekstā kravas pārvadājums ir uzskatāms par pakalpojumu sniegšanas līgumu un jurisdikcija būs divām tiesām: tajā vietā, kurā pārvadājums tiek iesākts (proti, krava nododama pārvadātājam), un tajā vietā, kurā krava piegādājama. Sk.: Magnus U., Mankowski P. (eds.). European Commentaries on Private International Law. Vol. I. Burssels Ibis Regulation. Köln: Otto Schmidt, 2016, pp. 241-242. Te gan ir jānorāda, ka Briseles Ibis regulas 7. pants nav piemērojams, ja atbildētāja domicila neatrodas kādā no Eiropas Savienības dalībvalstīm. Šādā situācijā tiesa, protams, nevarēs piemērot regulu, lai noteiktu teritoriālo jurisdikciju. 
Pirmā starp objektīvajām piesaistēm ir minēta atbildētāja dzīvesvieta. Šì piesaiste attiecas uz fiziskām personām. ${ }^{29}$ Atbildētāja dzīvesvieta ir faktisks kritērijs: proti, ir jākonstatē, vai attiecīgajā valstī fiziskā persona patiešām dzīvo. ${ }^{30}$ Šis kritērijs nav saistīts ar deklarēto dzīvesvietu vai kādu pienākumu informēt valsts institūcijas par dzīvesvietu. ${ }^{31}$

Otra piesaiste ir atbildētāja "galvenais uzṇēmums”. Balstoties uz CMR angḷu versiju, ir izteikts viedoklis, ka galvenais uzṇēmums var būt gan juridiskām personām, gan arī fiziskām personām, ja tās veic uzṇēmējdarbību. ${ }^{32}$ Savukārt CMR franču versija drīzāk norāda uz to, ka runa ir tikai par juridiskām personām. ${ }^{33}$ Šis jautājums nav līdz galam atrisināts. Vēl viens jautājums, par kuru mēdz būt diskusijas: vai runa ir par faktisko "uzņēmumu”, proti, par valsti, kurā tiek pieņemti lēmumi par uzṇēmuma darbību, vai arī tā reg̣istrācijas valsti. Vācu autori uzstāj, ka runa ir tikai par uzṇēmuma patieso sēdekli, proti, vietu, no kuras uzṇēmums tiek faktiski vadīts. ${ }^{34}$ To atbalsta arī daži angḷu autori, norādot, ka tikai uzṇēmuma faktiskās pārvaldes vietai ir nozīme. ${ }^{35}$ Citi angḷu autori uzskata, ka būtu vēlams, lai šo jēdzienu attiecinātu gan uz "patieso sēdekli", gan uz registrācijas valsti. ${ }^{36}$ Šis jautājums vēl aizvien nav pilnībā atrisināts, tomēr, saskaṇā ar dominējošo viedokli, runa ir tikai par uzñēmuma faktiskās pārvaldes vietu.

Ar jēdzienu "iestāde" vai "birojs" CMR saprot to, ko Latvijas tiesībās parasti dēvē par filiāli. Tātad gadījumos, ja pārvadājuma līgums ir slēgts ar filiāli, prasību var celt arī tajā vietā, kurā atrodas filiāle. Tomēr ir būtiski norādīt, ka runa ir tieši par atbildētāja filiāli. ${ }^{37}$ Prasīāja filiālei, pat ja tā ir slēgusi pārvadājuma līgumu, nav nozìmes.

Tiesību literatūrā tiek norādīts, ka iestādes/biroja jēdziena iztulkošanai kā papildu avotu varētu izmantot arī Eiropas Savienības tiesu praksi līdzīga jēdziena iztulkošanā Briseles Ibis regulas kontekstā. ${ }^{38}$ Būtiski norādīt, ka filiālei nevar pielīdzināt līgumisku aǵentu, kurš, pārstāvot atbildētāju, ir noslēdzis līgumu. ${ }^{39}$

Beidzot ir jānorāda uz tām piesaistēm, kas ir saistītas ar paša pārvadājuma veikšanu. Tādas CMR ir divas. Pirmā ir kravas nosūtīšanas vieta. Šeit ir svarīgi atzīmēt, ka runa ir par to vietu, kurā faktiski pārvadātājs saṇēma kravu. ${ }^{40}$ Ja šì

${ }^{29}$ Clarke M. A. 2014, p. 157.

30 Canaris C.-W. 2017, S. 650; Schmidt K. 2014, S. 1819; Theunis J. 1987, p. 150.

31 Canaris C.-W. 2017, S. 650; Schmidt K. 2014, S. 1819.

32 Ibid.

33 Franču versijā tiek lietots jēdziens siège principal, ko varētu tulkot kā "[uzṇēmuma] galveno sēdekli”. Sk.: Convention relative au contrat de transport international de marchandises par route (CMR). Pieejams: https://www.unidroit.org/fr/instruments/instruments-transport/cmr-fr [aplūkots 12.03.2021.].

${ }_{34}$ Mankowski P. 2019, p. 970; Canaris C.-W. 2017, S. 650-651; Schmid K. 2014, S. 1820.

35 Clarke M. A. 2014, p. 157.

${ }^{36}$ Messent A. 2000, p. 245. Sk. arī: Rodière P. The Convention on Road Transport: 10th Article. European Transport Law, 1971, Vol. 6, p. 576. Latvijas tiesu praksē var atrast uzskatu, ka valsti, kurā atrodas juridiskās personas galvenais uzṇēmums, nosaka pēc juridiskās personas juridiskās adreses. Sk.: Rēzeknes tiesas 5.03.2020. spriedums lietā Nr. C-0470-20. Pieejams: https://manas.tiesas.lv/eTiesasMvc/nolemumi/ pdf/415659.pdf [aplūkots 20.04.2021.].

37 Messent A. 2000, pp. 245-246.

${ }^{38}$ Kā norādījusi Eiropas Savienības Tiesa: "Pirmkārt, jēdzienā "filiāle" tiek prezumēta darījumu veikšanas centra esamība, kas ilgtermiņā ārēji izturas kā mātes uzṇēmuma atvasinājums. Šim centram ir jābūt vadībai, un tam materiālā ziṇā jābūt aprīkotam tā, lai tas būtu spējīgs slēgt darījumus ar trešajām personām un tām nebūtu tieši jāvēršas mātes uzṇēmumā." EST 05.07.2018. spriedums lietā C-27/17 AB “flyLAL Lithuanian Airlines” pret VAS “Starptautiskā lidosta "Rīga”" un AS “Air Baltic Corporation”, 59. rindkopa.

39 Clarke M. A. 2014, p. 158. Sk. arī: Theunis J. 1987, p. 150.

40 Mankowski P. 2019, p. 970; Canaris C.-W. 2017, S. 651; Schmidt K. 2014, S. 1821. 
vieta neatbilst tai, par kuru nosūtītājs un pārvadātājs ir vienojušies, tad jebkurā gadījumā nozīme ir tikai tai vietai, kurā faktiski krava ir nodota pārvadātājam. ${ }^{41}$ Otrā ir vieta, kura līgumā ir apzīmēta kā kravas piegādāšanas vieta. ${ }^{42}$ Šajā ziṇā CMR tulkojums latviešu valodā nav apmierinošs, jo tajā nav norādes uz to, ka šai vietai ir jābūt minētai pašā pārvadājuma līgumā. CMR labākai izpratnei ir jāizmanto tās autentiskās versijas angḷu un franču valodā. ${ }^{43} \mathrm{CMR}$ autentiskajās versijās ir runa tieši par vietu, kas apzīmēta kā kravas piegādāšanas vieta. ${ }^{44}$ Ja faktiskās piegādes vieta atšķiras no pavadzīmē norādītās, tad jurisdikcija ir jānosaka pēc tās vietas, par kuru puses ir vienojušās. ${ }^{45}$ Tiesību doktrīnā un praksē dalās viedokḷi par to, vai saskaṇā ar CMR 12. pantu pārvadātajam sniegtās norādes nogādāt kravu citā vietā ietekmēs arī jurisdikciju. ${ }^{46}$

\section{31(1). panta subjektīvā piesaiste: pušu vienošanās}

CMR 31(1). panta tulkojums latviešu valodā nav apmierinošs ne tikai attiecībā uz kravas piegādāšanas vietu. Tāpat ir grūti saprast frāzi "Par strīdīgiem jautājumiem, kas rodas, veicot pārvadājumus pēc šìs Konvencijas, prasītājs var ierosināt prāvu jebkurā Līgumslēdzēju Valstu norādītajā tiesā [..]”. CMR autentiskās versijas skaidri pasaka - runa ir par pušu tiesībām vienoties par tiesu, kurā varēs izskatīt strīdu. ${ }^{47}$ Proti, CMR l̦auj līguma pusēm izvēlēties vēl citu kompetentu tiesu. Tomēr puses var vienoties tikai par CMR līgumslēdzējas valsts tiesu. ${ }^{48}$ Šãda vienošanās būs saistoša ne tikai kravas nosūtītājam un pārvadātājam, bet arī visām citām personām, kuru tiesības būs atvasināmas no pārvadājuma līguma, jo īpaši kravas saṇēmējam. ${ }^{49}$ Piemēram, ja kravas saṇēmējs cels prasību pret pārvadātāju, tad arī viņš varēs to celt tās valsts tiesā, par kuru pārvadājuma līguma puses bija vienojušàs.

Attiecībā uz šādu vienošanos ir jāmin dažas īpatnības. Pirmkārt, tā nav ekskluzīva. Proti, neskatoties uz vienošanos, jebkurai no pusēm paliks tiesības celt prasību tajā valstī, kas atbilst CMR 31(1). pantā minētajiem kritērijiem. ${ }^{50}$ Tātad vienošanās var sniegt prasītājam tikai papildu opciju. Savukārt, ja puses ir vienojušās par kādas valsts tiesu ekskluzīvu jurisdikciju, tad arī šāda vienošanās netiks uzskatīta par ekskluzīvu. ${ }^{51}$

CMR 31(1). pantā nav nekas teikts par vienošanās formu. Daži avoti to izprot kā norādi uz formas brīvību; ${ }^{52}$ saskaṇā ar citiem tiesai ir jāpiemēro nacionālās

\footnotetext{
${ }^{41}$ Sk.: Schmidt K. 2014, S. 1821.

42 Mankowski P. 2019, p. 970; Canaris C.-W. 2017, S. 653; Schmidt K. 2014, S. 1821.

43 Sk.: Clarke M. A. 2014, p. 16.

44 Angḷu versijā: "the place designated for delivery is [..]”. Franču versijā: "[le lieu] prévu pour la livraison [..]".

${ }^{45}$ Clarke M. A. 2014, p. 159.

46 Par šādu risinājumu: Canaris C.-W. 2017, S. 653; Clarke M. A. 2014, p. 159. Uz viedokḷu pretrunību norāda: Schmidt K. 2014, S. 1821.

47 Piemēram, angḷu valodā norma ir formulēta šādi: "In legal proceedings arising out of carriage under this Convention, the plaintiff may bring an action in any court or tribunal of a contracting country designated by agreement between the parties and, in addition, in the courts or tribunals of a country within whose territory [..]."

${ }^{48}$ Clarke M. A. 2014, p. 159.

49 Messen A. 2000, p. 244; Loewe R. 1975, p. 64.

50 Clarke M. A. 2014, p. 160; Messen A. 2000, p. 245.

51 Mankowski P. 2019, p. 970.

52 Sk.: Canaris C.-W. 2017, S. 645.
} 
tiesības. ${ }^{53}$ Manā skatījumā, nnemot vērā, ka CMR nav normu, kas noteiktu, kāds likums regulē šādas vienošanās formālo spēkā esamību, nebūtu pareizi uzskatìt, ka CMR līdz ar to sniedz kādu autonomu regulējumu. Drīzāk būtu pamatots uzskats, ka šeit pastāv robs CMR regulējumā un Eiropas Savienības dalībvalsts tiesai būtu jāpiemēro Briseles Ibis regulas 25. panta noteikumi, lai to aizpildìtu.

Beidzot, ir viena būtiska atškiriība starp CMR 31(1). panta objektīvajām piesaistēm un subjektīvo piesaisti. Objektīvās piesaistes nosaka tikai starptautisko jurisdikciju, bet ne teritoriālo piekritību starp vienas valsts dažāāām tiesām. Turpretim pušu vienošanās var ietvert norādi uz konkrētu valsts tiesu un tādējādi mainìt teritoriālo piekritību. ${ }^{54}$ Tātad saskaṇā ar šo vienošanos prasìtājs varēs celt prasību papildus tieši tajā nacionālajā tiesā, par kuru puses ir vienojušās. Tomēr šāda vienošanās nevar mainīt nacionālo tiesu ratione materiae vai institucionālu piekritību. ${ }^{55}$ Piemēram, puses nevar vienoties, ka viṇu strīdu izskatīs apelācijas tiesa vai tiesa, kurai principā nav kompetences skatīt šādas lietas. Tādā gadījumā būtu pareizi uzskatīt, ka puses nav izdarījušas izvēli par labu kādai konkrētai tiesai un prasîtājs var vērsties jebkurā izvēlētās valsts tiesā, kura saskaṇā ar nacionālajām piekritības normām var lietu skatît.

\section{Secinājumi}

1. Strīdā, kas izriet no starptautiskā autopārvadājuma līguma, tiesai ir jāpiemēro CMR 31(1). pants, lai noteiktu starptautisko jurisdikciju un izlemtu, vai tā vispār ir tiesīga skatìt lietu.

2. CMR 31(1). pantā ir paredzētas divu veidu piesaistes: objektīvas un subjektīva. Objektîvās piesaistes ir saistîtas vai nu ar atbildētāja atrašanās vietu, vai arī ar pārvadājuma līguma izpildi. Subjektīvā piesaiste ir pušu vienošanās, ar kuru tās l̦auj izskatît strīdu kādai CMR līgumslēdzējas valsts tiesai.

3. Vienošanās par jurisdikciju nevar izslēgt prasītāja iespēju celt prasību citās valstīs, uz kurām norāda CMR 31(1). pants. Tomēr vienošanās var noteikt konkrētu tiesu, kurā prasītājs varēs celt prasību gan kādā no tām tiesām, kas minētas CMR 31(1). pantā, gan arī kādā citā līgumslēdzējas valsts tiesā. Proti, tādā veidā puses var atkāpties arī no teritoriālās piekritības normām starp vienas valsts tiesām.

\footnotetext{
${ }^{53}$ Messent A. 2000, p. 245; Theunis J. 1987, p. 149.

54 Schmidt K. 2014, S. 1822. Sk. arī: Rodière P. 1971, p. 575.

55 Putzeys J. 1981, p. 375.
} 